\title{
Some "Illegal Reasoning" of the First Year Undergraduate Students in Constructing Formal Proof
}

\author{
Hendarto Cahyono, \\ University of Muhammadiyah Malang \\ Malang, Indonesia \\ Email: hendartochy@gmail.com
}

\author{
Abdur Rahman, Toto Nusantara \\ State University of Malang \\ Malang, Indonesia
}

\begin{abstract}
This paper describes the difficulties and type of illegal reasoning of novice students in formulating formal proof specially on the associative property of addition operation of rational numbers. Although the problem is not so hard but for beginner students is not the case. The participants are first year students at University of Muhammadiyah Malang on second semester. Subjects are chosen based on answers that show difficulty in establishing verification related to conceptual understanding, referential reasoning, and organization of proof-writing. The framework that was used to analyze students' proof comprehension and construction actions and contributions, particularly their completeness and type of reasoning, is described in the paper. The findings of the study resonate closely with those of researchers in the developed world. Students' difficulties with how to begin proof, understanding of the rules and nature of proof, conceptual understanding, and proof techniques and strategies. Related with illegal reasoning, a novice student indicated generic reasoning, unable to make generalization, circular reasoning, and non-referential reasoning.
\end{abstract}

Keywords-formal proof, difficulties; proof construction; associative property, illegal reasoning

\section{INTRODUCTION}

Proof is the basis of mathematics and it is important for students to know what constitutes a proof, why proof is needed and how to construct proof to understand the structure of mathematics. Proof has been described as the "soul of mathematics" (Schoenfeld, 2009). NCTM (2000) has recognized the importance of proof by elevating it to one of five Process Standards for thinking mathematically, emphasizing that proof should be part of students' experiences across all grades. More recently, the Common Core Standards (2010) have reiterated the importance of justification as a mathematical practice.

The meaning of proof, its role and the way it is created, verified and accepted may vary from person to person and from community to community (Harel and Sowder, 2007). But the general purpose of proving is to verify, explain, communicate, and systematize statements into deductive systems (Almeida, 2000; Hersh, 1993).

Despite its central role in mathematical thinking, however, proof is challenging. Research has documented that students of all ages face difficulties in constructing rich mathematical arguments. Varies Studies (Moore, 1994; Harel and Sowder, 1998; Dreyfus, 1999; Almeida, 2000; Jones, 2000; Weber, 2001; Recio and Godino, 2001; Selden and Selden, 2003; Baker and Campbell, 2004; Edwards and Ward, 2004; Weber, 2004; Stylianides, Stylianides and Philippou, 2007) indicate that undergraduate students' conception of proof is deficient and they have difficulties in constructing proofs.

Moore (1994) found seven major sources of students' difficulties in constructing proofs, namely: (1) The students did not know the definitions. (2) The students had little intuitive understanding of the concepts. (3) The students' concept images were inadequate for doing the proofs. (4) The students were unable, or unwilling, to generate and use their own examples. (5) The students did not know how to use definitions to obtain the overall structure of proofs. (6) The students were unable to understand and use mathematical language and notation. And (7) The students did not know how to begin proofs. Meanwhile Gibson (1998) concluded that students' difficulties with mathematical proof are related to the following factors: 1) understanding of the rules and nature of proof, (2) conceptual understanding, (3) proof techniques and strategies, (4) cognitive load.

Selden and Selden (2003), described a number of types of reasoning errors and underlying misconceptions. They also classified reasoning errors according to their logical characteristics, that is, according to whether they arise from difficulties in generalization, use of theorems, notation and symbols, nature of proof, or quantification. Some of these errors are beginning with the conclusion, using inverse of a theorem, overextended symbols, weakening the theorem, notational inflexibility, misuse of theorems, ignoring and extending quantifiers.

Baker and Campbell (2004) noted that students 
struggle with understanding the process of proof construction and the precision in writing mathematics. They also found that students demonstrate some misconceptions concerning applying rules of logic to proof construction. Baker and Campbell listed their observations from a transition to proof course as: (1) Students struggle with the correct use of logical arguments (2) Students often attempted to write a proof prior to fully evaluating the statement and its implications (3) Students struggle with the precision of mathematical language

Edwards and Ward (2004), investigated the students' use of definitions in constructing proofs and found that many students don't use and categorize mathematical definitions the way mathematicians do, also they can't understand the distinction between everyday language and mathematical language. Knapp (2005) concluded that students' difficulties in constructing proof fit into two categories. First students struggle with the logic, language and culture of the proof as determined by the community. Second students lack the domain specific knowledge, such as definitions, theorems, heuristics and the ability to generate examples.

According to Weber (2006) research deal with cause of students' difficulties with mathematical proof can be categorized into three classes. The first cause of students' difficulties is that they often possess an inaccurate conception of what constitutes a mathematical proof. A second cause is that they don't have an understanding of a theorem or a concept and systematically misapply it. Third reason is that they do not have the decision-making strategies to do. However, to perform mathematical proofs, when faced with deadlock, students using shortcuts by unknown justification. This actions encourage students to use illegal reasoning.

The purpose of this research is to know students' difficulties and type of illegal reasoning when construct formal proof.

\section{METHOD}

Researchers want to know the thinking process of students in preparing formal proof and trace the difficulties and faulty reasoning used. Therefore, this research uses qualitative-explorative research type. The research subject was chosen from first year students of Mathematics Education Study Program at University of Muhammadiyah Malang in academic year 2016/2017 which had difficulties in formulating formal proof. The main instrument in this study is the researcher himself and its supporting instruments related to the work of proof of worksheets, interviews, and audio visual recordings.

Subjects are given a worksheet relating to the proof of associative property of operations. Worksheet about proving of the associative property of some binary operations consists of 4 questions, but in this paper researcher is more concerned with the first problem as shown in Table 1.
Diberikan satu himpunan beserta operasi biner yang terdefinisikan pada hinipunan tersebut. Buktikan keberlakuan sifat asosiatif operasi pada himpunan yang terkait berikut ini.

1. Operasi penjumlahan pada Himpunan hilangan peeahan/rasional

$$
\text { Buktikan bahwa: } \forall a, b, c, d, e, f \in \mathbb{Z} ; b, d, f \neq 0 ;\left(\frac{a}{b}+\frac{c}{d}\right)+\frac{e}{f}=\frac{a}{b}+\left(\frac{c}{d}+\frac{e}{f}\right)
$$

Figure 1: Instrument for Research

Subjects are chosen based on answers that show difficulty in establishing formal proof verification related to conceptual understanding, referential reasoning, and organization of proof-writing. Task-based interviews are needed to track the thinking process and possible causes of errors.

\section{RESULT}

Based on the results of the students' responses to the task of establishing formal proof, among 43 students, 35 students performed the correct steps and reasons, 5 people carried out the steps correctly, but were not followed with the appropriate reasons, 2 persons with incomplete task, and a student failed to complete the task. A Student who fails to complete a task is considered a case in this paper. This subject is interesting to note because the task given is considered very basic, but encountered various obstacles

\section{DISCUSSION}

We hereby present a novice students' responses to test items together with the interview extracts when their solutions were discussed at a later stage (The names used is pseudonym). One of the most occurrences of reasoning errors is the misuse of the principle of addition and multiplication for fraction. These errors are still seen in the first year College students.

In Question of this study (Figure 1), students were given the rational number in form of fraction of two integers. Students were asked to prove associative property of addition operation for fraction. Even though it is not too hard problem, but some students face difficulty to prove this property.

\section{Generic Reasoning}

The subject $\mathrm{S}$ begins to prove the statement with a specific case as generic reasoning. A generic proof reasons is an action proof from a particular example that acts as a prototype for a class of examples and be interpreted as representing a general situation (CadwalladerOlsker, 2011). In this step she tries to convince with a certain number that satisfies the equation. He believes that equations which still contain variables do not have the truth of the relation. The reasons stated are not operable. Taking some numerical 
values can be known either true or false for equations that will be proven. At first he felt he was doing the correct proof. This can be seen from the fact that the decision of the selected number satisfies the equation to be proved. It is like in the following interview between Researcher (R) and Subject $(\mathrm{S})$ below:

\section{TABEL 1: INTERVIEW ABOUT GENERIC REASONING}

\begin{tabular}{|c|c|c|}
\hline $\mathrm{R}$ & : & $\begin{array}{l}\text { Good Afternoon, please sit down. There is } \\
\text { something I want to ask you in some parts of } \\
\text { the answers you have written related to } \\
\text { yesterday's problem }\end{array}$ \\
\hline $\mathrm{S}$ & $:$ & What is it sir? \\
\hline $\mathrm{R}$ & : & $\begin{array}{l}\text { We look back at your answer. } \\
\text { When at beginning to solve the problem of } \\
\text { proof, you provided with putting letters } a, b, c \\
\text { and so on with a certain number. Can you } \\
\text { explain the meaning? }\end{array}$ \\
\hline $\mathrm{S}$ & : & $\begin{array}{l}\text { I think it's a matter of purpose to show } \\
\text { equality. So ... yes I take a certain number to } \\
\text { show the truth.. }\end{array}$ \\
\hline $\mathrm{R}$ & $:$ & Why are specific numbers and all different? \\
\hline $\mathrm{S}$ & : & $\begin{array}{l}\text { Yes, I change the numbers, so that it can be } \\
\text { operated and the results can be calculated } \\
\text { directly and clear. To make easier, I take } 1 \text { to } \\
6 .\end{array}$ \\
\hline $\mathrm{R}$ & : & $\begin{array}{l}\text { So, if it is not an integer, do you think it cannot } \\
\text { be counted? }\end{array}$ \\
\hline $\mathrm{S}$ & : & $\begin{array}{l}\text { Lha,... It just to make sure, that's fractions } \\
\text { should be equal, that is } 50 / 24 \text { equal to } 25 / 12 \\
\text { can be check directly }\end{array}$ \\
\hline
\end{tabular}

Jaush: mis, $a=1, b=2, c=3, d=1, a=5, f=6$

$$
\begin{gathered}
\left(\frac{a}{b}+\frac{5}{d}\right)+\frac{2}{f}=\frac{a}{b}+\left(\frac{6}{4}+\frac{c}{f}\right) \\
\left(\frac{1}{2}+\frac{5}{4}\right)+\frac{5}{6}=\frac{1}{2}+\left(\frac{3}{4}+\frac{5}{6}\right) \\
\left(\frac{5}{4}\right)+\frac{5}{6}=\frac{1}{2}+\left(\frac{12}{12}\right) \\
\frac{50}{24}=\frac{25}{12}
\end{gathered}
$$

Fig 2: Students' Generic Thinking with a certain number

\section{Unable to Make Generalization}

After metacognition of what has been done in establishing formal proof, the subject feels that his work is still not as expected. He conscious that the proving could not be done by taking a specific example and canceling the work by giving cross sign at the end of sentence. The next step to think about is the general nature that can be used to make evidence. He thinks of distributive and associative nature. The use of this trait also fails to overcome the essence of the problem which must be proved ie the associative properties of the given

\begin{tabular}{|c|c|c|}
\hline $\mathrm{R}$ & : & $\begin{array}{l}\text { But in the end of equality, there is a cross sign, } \\
\text { what that means? Is it wrong counting? }\end{array}$ \\
\hline $\mathrm{S}$ & . & Hm.. I felt doubt sir... is that what to be desired? \\
\hline $\mathrm{R}$ & : & In what kind do you doubt? \\
\hline $\mathrm{S}$ & : & $\begin{array}{l}\text { In terms of proving task, usually should be in } \\
\text { general, cannot be specific. So Ifelt it was wrong }\end{array}$ \\
\hline $\mathrm{R}$ & : & Ok. Next what did you write?. \\
\hline $\mathrm{S}$ & : & $\begin{array}{l}\text { Yes as it had to write a general form, so .. yes I } \\
\text { wrote again }\end{array}$ \\
\hline $\mathrm{R}$ & : & Can you clarify more? \\
\hline $\mathrm{S}$ & : & $\begin{array}{l}\text { In general form, I have to use its' properties, like } \\
\text { distributive or associative }\end{array}$ \\
\hline $\mathrm{R}$ & : & And did you get the results that you want? \\
\hline $\mathrm{S}$ & : & $\begin{array}{l}\text { Not yet sir, because form } a / b+c / d \text { doesn't have } \\
\text { value sir.. }\end{array}$ \\
\hline
\end{tabular}
operation (Interview Table 3 )

\section{TABLE 2: TRYING TO FIND GENERALIZATION}

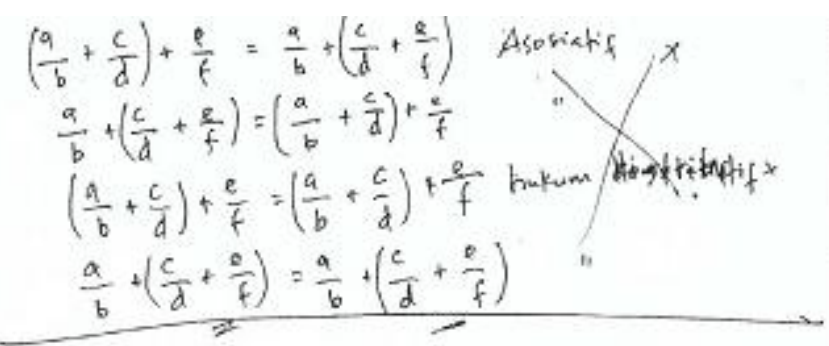

Figure 3: Faulty to Generalize

\section{Circular Reasoning}

The third faulty of what subject does is a circular reasoning. The circular reasoning here is justifying a consequence what should be prove, to be a premise. So the consequences serve as hypotheses. At this moment, associative is a property which must be proven. But it is assumed to be given. Of course it's an illegal reasoning. 
TABLE 3: CIRCULAR REASONING

\begin{tabular}{|c|c|c|}
\hline $\mathrm{R}$ & $:$ & Then ... what's next? \\
\hline $\mathrm{S}$ & $:$ & $\begin{array}{l}\text { Yes because in the fraction hold on commutative } \\
\text { law, that means I can swap position.. }\end{array}$ \\
\hline $\mathrm{R}$ & $:$ & So what conclusions are obtained. \\
\hline $\mathrm{S}$ & $:$ & Yes sir, the left side is equal to the right side \\
\hline $\mathrm{R}$ & : & But that's what you want to prove, isn't it? \\
\hline $\mathrm{S}$ & $:$ & That's why I feel hesitate \\
\hline $\mathrm{R}$ & & Why? \\
\hline $\mathrm{S}$ & & $\begin{array}{l}\text { Circular sir ... (she laughs ..) so I made cross sign } \\
\text { again }\end{array}$ \\
\hline $\mathrm{R}$ & & What to do next? \\
\hline $\mathrm{S}$ & & I try to add like regular fractions. \\
\hline $\mathrm{R}$ & & Where did you get such an idea? \\
\hline $\mathrm{S}$ & & $\begin{array}{l}\text { When I do problem related with counting, I should } \\
\text { execute first the expression in the brackets. Then I } \\
\text { try to develop from there. It find out that the left } \\
\text { side is equal to the right side }\end{array}$ \\
\hline
\end{tabular}

\section{Non Referential Reasoning.}

The subject tries to solve the problem by performing a numerical operation by direct execution on each side of the equation. She does every expression in the bracket. On the right side She was swapped positions. She assumed that the expression within the brackets must be taken precedence. Therefore, must be placed in front. This assumption is clearly no reference. Then this is categorized as non-referential reasoning. This reasoning has the potential to fail if the position exchange does not take into account the operation sign.

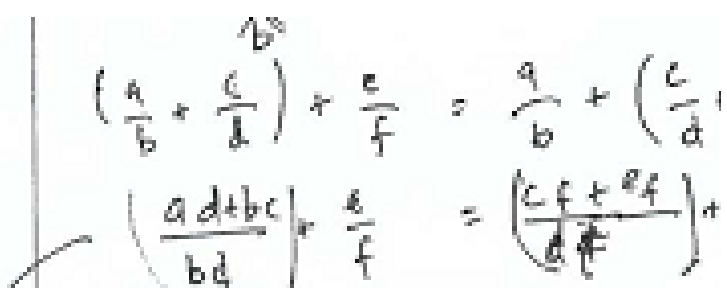

Fig 4: Non Referential Work

Furthermore, in performing variable operations, the subject looks confusion on "cross operation" on the multiplication of rational numbers. She just remembered that on multiplication of fraction use cross rule. $\frac{a}{b} \cdot \frac{c}{d}=$ $\frac{a \cdot d}{b \cdot c}$ instead of $\frac{a}{b}=\frac{c}{d}$ imply $a \cdot d=b \cdot c$. So this confusion impacted to student assumption that $\frac{a}{b}+\frac{c}{d}=\frac{a \cdot d}{b \cdot c}$ like she did. One thing that is conceptually not yet comprehensively understood.

Table 4:

\begin{tabular}{|c|c|c|}
\hline $\mathrm{R}$ & : & $\begin{array}{l}\text { Wait } \ldots, \text { on this step, you change position } a / b \\
\text { and }(c / d+e / f) \text {, why? }\end{array}$ \\
\hline$S$ & : & $\begin{array}{l}\text { Yes sir, I have to execute something in the } \\
\text { bracket firstly, so form }(c / d+e / f) \text { must be in } \\
\text { earlier. }\end{array}$ \\
\hline $\mathrm{R}$ & : & Is there any guarantee for \\
\hline $\mathrm{S}$ & : & I think It was based on cc \\
\hline $\mathrm{R}$ & : & And then? \\
\hline $\mathrm{S}$ & : & $\begin{array}{l}\text { I try to solve by doing direct calculation in each } \\
\text { side. }\end{array}$ \\
\hline $\mathrm{R}$ & $:$ & How do you do the calculations directly? \\
\hline $\mathrm{S}$ & : & $\begin{array}{l}\text { I just remember that }(a d+b c) b d+e / f=(\text { ade } \\
+b c e) / b d f \text { on the left side and }(c f+d f) d f+a / \\
b=(\text { acf }+ \text { aef }) / b d f \text { on the right side. But I feel } \\
\text { it is an illegal operation, so I canceled what I did } \\
\text { by putting a circle }\end{array}$ \\
\hline
\end{tabular}

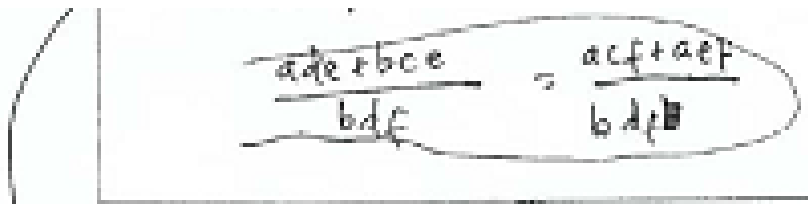

Figure 5: Wrong calculation

Table 5:

\begin{tabular}{|l|l|l|}
\hline $\mathrm{R}$ & $:$ & Why do you think like that? \\
\hline $\mathrm{S}$ & $:$ & Because this is an addition operation for fraction \\
\hline $\mathrm{R}$ & $:$ & And then... \\
\hline $\mathrm{S}$ & $:$ & I do with cross product. And finally, I got this one \\
\hline
\end{tabular}

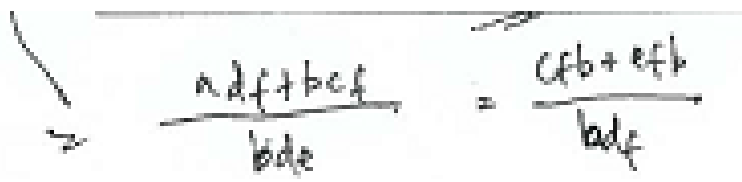

Fig 5: unsolved work

\section{CONCLUSION}

Based on the results of this study can be concluded that 
the problem of construction of formal prove for novice students are (1) difficulties with how to begin proof, (2) understanding of the rules and nature of proof, (3) conceptual understanding, and (3) proof techniques and strategies. Related with illegal reasoning, a novice student (1) indicated generic reasoning, (2) unable to make generalization, (3) circular reasoning, and (4) nonreferential reasoning. Based on these findings, this research can be developed about what kind of instructional activities can be designed to overcome these difficulties

\section{REFFERENCE}

[1] Almeida, D. A survey of mathematics undergraduates' interaction with proof: some implications form mathematics education. International Journal of Mathematical Education in Science and Technology, 31(6), 869-890 (2000).

[2] Almeida, D. Engendering proof attitudes: Can the genesis of mathematical knowledge teach us anything? International Journal of Mathematical Education in Science and Technology, 34(4), 479-488 (2003).

[3] Anapa, P., Şamkar., H., Investigation of undergraduate students' perceptions of mathematical proof, Procedia Social and Behavioral Sciences 2, 2700-2706, doi:10.1016/j.sbspro.2010.03.399 (2010),

[4] Baker,D.,\&Campbell,C Fostering the development of mathematical thinking: Observations from a proofs course. Primus, 14(4),345-353 (2004).

[5] Bieda, Kristen N., Enacting Proof-Related Tasks in Middle School Mathematics: Challenges and (2010), Opportunities, Journal for Research in Mathematics Education, Vol. 41, No. 4, pp. 351-382

[6] CadwalladerOlsker, T, What Do We Mean by Mathematical Proof?, Journal of Humanistic Mathematics, Volume 1 Issue 1, 33-60. DOI: 10.5642/jhummath.201101.04 (2011).

[7] Dreyfus, TWhy Johnny Can't Prove. Educational Studies in Mathematics, 38(1), 85- 109 .(1999).

[8] Edwards, B.S. \& Ward, M.B. Surprises from Mathematics Education Research: Student (Mis)use of Mathematical Definitions. The American Mathematical Monthly, 111, 411-424 (2004).

[9] Gibson, DStudents' use of diagrams to develop proofs in an introductory analysis course. Students' proof schemes. In E. Dubinsky, A. Schoenfeld, \& J. Kaput(Eds.), Research on Collegiate Mathematics Education, III, 284307. AMS .(1998).

[10] Harel, G.\& Sowder, L. Students' proof schemes. In E. Dubinsky, A. Schoenfeld, \& J. Kaput (Eds.), Research on Collegiate Mathematics Education, III, 234-283. AMS (1998).

[11] Harel, G.,Selden, A.\&Selden, J Advanced Mathematical Thinking. In A.Gutierrez, P. Boero(eds.),Handbook of Research on the Pschology of Mathematics education: Past, Present and Future, 147-172 .(2006).

[12] Inglis, M., Alcock, L., Expert and Novice Approaches to Reading Mathematical Proofs, Journal for Research in
Mathematics Education, Vol. 43, No. 4, pp. 358-390 (2012),

[13] Jones, K The student experience of mathematical proof at university level, International Journal of Mathematical Education in Science and Technology, 31,1, 53-60. . (2000).

[14] Knapp, J. Learning to prove in order to prove to learn. (2005) URL:

http://mathpost.asu.edu/ sjgm/issues/2005_spring/SJGM _knapp.pdf

[15] Moore, R.C. Making the transition to formal proof. Educational Studies in Mathematics, 27, 249-266 (1994)

[16] Moore, Robert C., Mathematics Professors'Evaluation of Students'Proofs:A Complex Teaching Practice. Int. J. Res. Undergrad. Math. Ed 2:246-278 DOI 10.1007/s40753-016-0029-y (2016),

[17] Pedemonte, B.How can the relationship between argumentation and proof be analyzed? Educational Studies in Mathematics, 66, 23-41 .(2007)

[18] Recio, A. M. \& Godino, J. D Instutional and Personal Meanings of Mathematical Proof, Educational Studies in Mathematics, 48, 1, 83-89.(2001).

[19] Rogers, Kimberly C., Steele, Michael D, Graduate Teaching Assistants' Enactment of Reasoning-andProving Tasks in a Content Course for Elementary Teachers, Journal for Research in Mathematics Education, Vol. 47, No. 4 (July 2016), pp. 372-419 (2016),

[20] Selden,A.,\&Selden,JErrors and misconceptions in college level theorem proving. Technical Report, Mathematics Department, Tennesse Technological University. 10.05.2008 tarihinde erişildi .(2003) URL: http://www.math.tntech.edu/techreports/TR_2003_3.pdf

[21] Selden,A.,\&Selden,J Overcoming students' difficulties in learning to understand and construct proofs. Technical Report, Mathematics Department, Tennesse Technological University. (2007). URL: http://www.math.tntech.edu/techreports/TR_2007_1.pdf

[22] Selden,A.,\&Selden,J Teaching proving by coordinating aspects of proofs with students' abilities. Technical Report, Mathematics Department, Tennesse Technological University .(2007) URL: http://www.math.tntech.edu/techreports/TR_2007_2.pdf

[23] Smith, J.C.,(2006). A sense-making approach to proof: Strategies of students in traditional and problem-based number theory courses. Journal of Mathematical Behaviour, 25, 73- 90.

[24] Stylianides, A. J., Stylianides, G. J., \& Philippou, G.N. Undergraduate students' understanding of the contraposition equivalence rule in symbolic and verbal contexts. Educational Studies in Mathematics,55, 133162. (2004).

[25] Stylianides, Andras J. Proof and Proving in School Mathematics, Journals for Research in Mathematics Education, Vol. 38, No. 3, 289-321 (2007),

[26] Stylianides, G. J., Stylianides, A. J., \& Philippou, G.N. Preservice teachers' knowledge of proof by mathematical induction. Journal of Mathematics Teacher Education, 10, 145-166. (2007). 
[27] Stylianides, Gabriel J., Stylianides, Andreas J., Facilitating the Transition from Empirical Arguments to Proof, Journal for Research in Mathematics Education, Vol. 40, No. 3 (May, 2009), pp. 314-352 (2009),

[28] Stylianou, Despina A., Blanton, Maria L., Rotou, OuraniaUndergraduate Students'Understanding of Proof:Relationships Between Proof Conceptions, Beliefs, and Classroom Experiences with Learning Proof, Int. J. Res. Undergrad. Math. Ed. 1:91-134 DOI 10.1007/s40753-015-0003-0 , (2015)

[29] Syamsuri, Purwanto, Subanji, Irawati, S., (2016), Characterization of students formal-proof construction in mathematics learning, Communications in Science and Technology 1(2) $42-50$ (2016)

[30] Weber, K. (2004). A Framework for Describing the Processes that Undergraduates Use to Construct Proofs. In M. J.Hoines \& A. B. Fuglestad (Eds.) International Group for the Psychology of Mathematics Education, 28th, Bergen, Norway, 14-18

[31] Weber, KStudent difficulty in constructing proof: The need for strategic knowledge. Educational Studies in Mathematics, 48(1), 101-119. .(2001).

[32] Weber, K.(2006). Investigating and Teaching the Processes Used to Construct Proofs. In F.Hitt, G.Harel \& A. Selden(Eds.), Research in Collegiate Mathematics Education, VI, 197-232. AMS.

[33] Weber, K., How Mathematicians Determine if an Argument Is a Valid Proof, Journals for Research in Mathematics Education, Vol. 39, No. 4, 431-459 (2008) 